\title{
The influences of historic lake trophy and mixing regime changes on long-term phosphorus fraction retention in sediments of deep eutrophic lakes: a case study from Lake Burgäschi, Switzerland
}

\author{
Luyao Tu ${ }^{1}$, Paul Zander ${ }^{1}$, Sönke Szidat ${ }^{2}$, Ronald Lloren $^{3,4}$, and Martin Grosjean ${ }^{1}$ \\ ${ }^{1}$ Oeschger Centre for Climate Change Research and Institute of Geography, University of Bern, Bern, Switzerland \\ ${ }^{2}$ Oeschger Centre for Climate Change Research and Department of Chemistry and Biochemistry, \\ University of Bern, Bern, Switzerland \\ ${ }^{3}$ Department of Earth Science, ETH Zürich, Zürich, Switzerland \\ ${ }^{4}$ Eawag, Swiss Federal Institute of Aquatic Science and Technology, Dübendorf, Switzerland
}

Correspondence: Luyao Tu (luyao.tu@giub.unibe.ch)

Received: 25 September 2019 - Discussion started: 4 November 2019

Revised: 8 April 2020 - Accepted: 17 April 2020 - Published: 20 May 2020

\begin{abstract}
Hypolimnetic anoxia in eutrophic lakes can delay lake recovery to lower trophic states via the release of sediment phosphorus $(\mathrm{P})$ to surface waters on short timescales in shallow lakes. However, the long-term effects of hypolimnetic redox conditions and trophic state on sedimentary $\mathrm{P}$ fraction retention in deep lakes are not clear yet. Hypolimnetic withdrawal of P-rich water is predicted to diminish sedimentary $\mathrm{P}$ and seasonal $\mathrm{P}$ recycling from the lake hypolimnion. Nevertheless, there is a lack of evidence from well-dated sediment cores, in particular from deep lakes, about the long-term impact of hypolimnetic withdrawal on sedimentary P retention. In this study, long-term sedimentary $\mathrm{P}$ fraction data since the early 1900s from Lake Burgäschi provide information on benthic $\mathrm{P}$ retention under the influence of increasing lake primary productivity (sedimentary green-pigment proxy), variable hypolimnion oxygenation regimes ( $\mathrm{Fe} / \mathrm{Mn}$ ratio proxy), and hypolimnetic withdrawal since 1977. Results show that before hypolimnetic withdrawal (during the early 1900s to 1977), the redoxsensitive Fe/Mn-P fraction comprised $\sim 50 \%$ of total $\mathrm{P}(\mathrm{TP})$ in the sediment profile. Meanwhile, long-term retention of total $\mathrm{P}$ and labile $\mathrm{P}$ fractions in sediments was predominantly affected by past hypolimnetic redox conditions, and $\mathrm{P}$ retention increased in sedimentary $\mathrm{Fe}$ - and $\mathrm{Mn}$-enriched layers when the sediment-overlaying water was seasonally oxic. However, from 1977 to 2017, due to eutrophicationinduced persistent anoxic conditions in the hypolimnion and
\end{abstract}

to hypolimnetic water withdrawal increasing the $\mathrm{P}$ export out of the lake, net burial rates of total and labile $\mathrm{P}$ fractions decreased considerably in surface sediments. By contrast, refractory $\mathrm{Ca}-\mathrm{P}$ fraction retention was primarily related to lake primary production. Due to lake restoration since 1977 , the $\mathrm{Ca}-\mathrm{P}$ fraction became the primary $\mathrm{P}$ fraction in sediments (representing $\sim 39 \%$ of total $\mathrm{P}$ ), indicating a lower $\mathrm{P}$ bioavailability of surface sediments. Our study implies that in seasonally stratified eutrophic deep lakes (like Lake Burgäschi), hypolimnetic withdrawal can effectively reduce $P$ retention in sediments and potential for sediment $P$ release (internal P loads). However, after more than 40 years of hypolimnetic syphoning, the lake trophic state has not improved nor has lake productivity decreased. Furthermore, this restoration has not enhanced water column mixing and oxygenation in hypolimnetic waters. The findings of this study are relevant regarding the management of deep eutrophic lakes with mixing regimes typical for temperate zones.

\section{Introduction}

Phosphorus (P) eutrophication in freshwater lakes is a global problem and has been a matter of concern to the public for several decades. In lakes where the external $\mathrm{P}$ loading has been reduced, internal $\mathrm{P}$ loading (sediment $\mathrm{P}$ release to surface waters) is widely recognized as the key factor affecting 
lake trophic status and delaying lake recovery from eutrophication (Burley et al., 2001; Trolle et al., 2010). Considerable work has been done on sediment $\mathrm{P}$ speciation to evaluate sediment $P$ release potentials and implications for lake restoration management (Gonsiorczyk et al., 1998; Ribeiro et al., 2008).

The paradigm that oxygen levels control the sediment $\mathrm{P}$ release via reductive dissolution of the $\mathrm{Fe}-\mathrm{P}$ fraction in surface sediments has been accepted as the classic model for a long time (Einsele, 1936, 1938; Moosmann et al., 2006). Under anoxic conditions, $\mathrm{P}$ bound to redox-sensitive $\mathrm{Fe}$ and $\mathrm{Al}-\mathrm{Fe}$ (oxyhydr)oxides can be potentially released from surface sediments into lake water (Burley et al., 2001), which was supported by numerous short-term (over the course of days or a season) laboratory or in situ studies (Chen et al., 2018; Smith et al., 2011). Based on this paradigm, it was assumed that an oxic sediment-water interface might limit the release of $\mathrm{Fe}-\mathrm{P}$ from sediments and therefore improve $\mathrm{P}$ retention in lake sediments. However, the restoration measures with artificial hypolimnetic oxygenation/aeration applied in eutrophic lakes proved to have only short-lasting effects and no direct long-term effects on internal P loading and redox-dependent sediment $\mathrm{P}$ retention (Gächter, 1987; Gächter and Wehrli, 1998; Moosmann et al., 2006; Hupfer and Lewandowski, 2008). Gächter and Müller (2003) and Moosmann et al. (2006) further argued that, on multidecadal or longer timescales, $\mathrm{P}$ retention in lake sediments might eventually primarily depend on the P-binding capacity of anoxic sediments and sediment composition (e.g., Fe, Mn, $\mathrm{Al}$, and $\mathrm{Ca}$ contents). Nevertheless, until now, there has been a lack of evidence from well-dated sediment cores, and there is still a need to know which processes may have a dominant influence on sediment $\mathrm{P}$ fraction retention on longer timescales (i.e., decades or more). This information is crucial for predicting and ultimately managing sediment $\mathrm{P}$ release, especially in deep lakes, because hypolimnetic anoxia in deep lakes can lead to large loads of sediment $P$ release. In contrast to the well-established studies about sediment $\mathrm{P}$ speciation in shallow polymictic lakes (e.g., Kaiserli et al., 2002; Søndergaard et al., 2001; Cavalcante et al., 2018), there are only a few studies available from seasonally stratified deep lakes. Furthermore, eutrophication has been demonstrated to affect sediment $P$ release via controlling hypolimnetic anoxia and lake mixing regime in seasonally stratified deep lakes (Tu et al., 2019a). It is not yet fully understood whether and how lake trophic levels and hypolimnetic anoxia can influence the long-term behavior of sedimentary $\mathrm{P}$ fraction retention in deep lakes.

The restoration technique of hypolimnetic withdrawal has been frequently applied in seasonally stratified lakes in Europe (Kucklentz and Hamm, 1988; Nürnberg, 2007), whereby P-enriched water from the hypolimnion is discharged directly into the lake outflow. This restoration technique has been shown to efficiently reduce $\mathrm{P}$ concentrations in lake waters (Nürnberg, 2007). Hypolimnetic withdrawal was also expected to reduce $\mathrm{P}$ retention in sediments and seasonal $\mathrm{P}$ recycling from the lake hypolimnion to the upper waters, for example, in Lake Mauen, a shallow eutrophic lake (maximum depth: $6.8 \mathrm{~m}$; Gächter, 1976). However, there is a lack of empirical evidence from sedimentary $\mathrm{P}$ fraction data, which provide valuable information on possible sediment $P$ release characteristics and the potential of internal $P$ loadings. Furthermore, for deep lakes, the long-term influence of this restoration on sedimentary $\mathrm{P}$ release potential is unclear.

The objectives of this study were to (1) explore the main factors controlling long-term changes of $\mathrm{P}$ fraction retention in sediments of deep lakes, (2) investigate how sediment $P$ fraction retention responds to changes in lake eutrophication and hypolimnetic anoxia of the past prior to anthropogenic eutrophication, (3) examine the long-term effects of lake hypolimnetic withdrawal restoration on sedimentary $\mathrm{P}$ fraction retention in seasonally stratified deep lakes, and (4) evaluate with sediment P data the predictions from Gächter (1976) that hypolimnetic withdrawal should result in reduced total $\mathrm{P}$ content in sediments and sediment $\mathrm{P}$ release to lake water. To achieve these objectives, we investigated short sediment cores from Lake Burgäschi, a deep eutrophic lake on the Swiss Plateau. Sedimentary green pigments (chlorophylls and diagenetic products) inferred from hyperspectralimaging (HSI) scanning and XRF-inferred $\mathrm{Fe} / \mathrm{Mn}$ ratios primarily reflect lake trophic-state evolution (aquatic primary productivity) and hypolimnetic oxygenation, respectively. A sequential $\mathrm{P}$ extraction with five $\mathrm{P}$ fractions was performed to uncover $\mathrm{P}$ fractionation in sediment profiles. We combined all data to identify the dominant factors responsible for temporal changes in $\mathrm{P}$ fraction retention.

Lake Burgäschi is an excellent study site because there were substantial changes in lake trophic levels and possibly lake mixing regimes since the last century (Guthruf et al., 1999; van Raden, 2012), and exceptionally long historical and limnological survey data are available for most of the last 50 years. Hypolimnetic withdrawal restoration has been in operation since 1977.

\section{Study site}

Lake Burgäschi $\left(47^{\circ} 10^{\prime} 8.5^{\prime \prime} \mathrm{N}, 7^{\circ} 40^{\prime} 5.9^{\prime \prime} \mathrm{E}\right)$ is a small lake located on the Swiss Plateau (Fig. 1a). It has a very restricted catchment $\left(3.2 \mathrm{~km}^{2}\right)$. The catchment area geologically belongs to the Molasse basin and mostly consists of carbonaterich sandstone and mudstone (Schmid et al., 2004). The kettle hole lake was formed after the retreat of the Rhone glacier (ca. 19 kyr BP; Rey et al., 2017). Currently the maximum water depth is $\sim 31 \mathrm{~m}$, which is quite deep in contrast to the small surface area of $0.21 \mathrm{~km}^{2}$ (Guthruf et al., 1999). The mean retention time of the lake water is $\sim 1.4$ years (Nürnberg, 2007). The lake has several small inflows in the southwest (Rey et al., 2017) and one outflow in the north (Fig. 1c). 


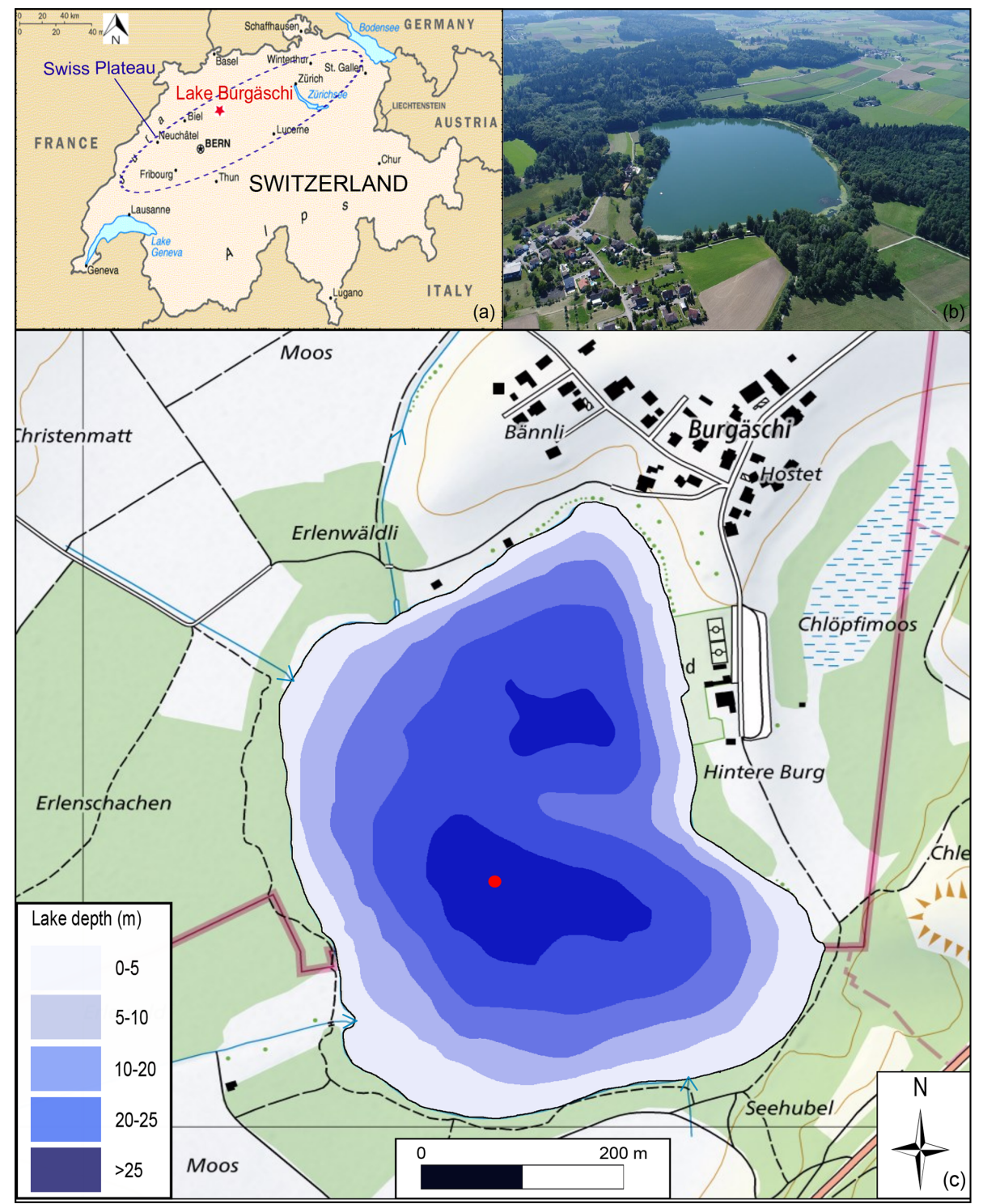

Figure 1. Study site. (a) Aerial map of Switzerland and the Swiss Plateau. Lake Burgäschi is indicated by the red asterisk. (b) Photo of Lake Burgäschi and catchment (C) Google Maps 2018). (c) Bathymetric map of Lake Burgäschi adapted from Guthruf et al. (1999). The red dot indicates the coring site (color figure online). Green areas around the lake indicate forests, and white areas indicate agricultural land. Inflow and outflow to the lake are indicated by blue arrows (topographic maps: (C) swisstopo).

Since the 19th century, the lake's water level has been lowered several times to create farmland, with the most recent lowering (up to $2 \mathrm{~m}$ ) between 1943 and 1945 (Guthruf et al., 1999). Agricultural area currently covers $\sim 55 \%$ of the lake catchment, and $\sim 29 \%$ is forested. The lake region experiences a warm humid continental climate (Dfb; KöppenGeiger classification). The mean annual air temperature is $9^{\circ} \mathrm{C}$, and the warmest month is July (mean temperature of $\left.19^{\circ} \mathrm{C}\right)$.

Lake Burgäschi has been highly productive (eutrophic to highly eutrophic state) since the 1970s, with high algal-biomass production and anoxic conditions in the hy- polimnion (Guthruf et al., 1999, 2013). The eutrophication in Lake Burgäschi has been linked to increased agricultural $P$ inputs via drainage into the lake in the second half of the 20th century (Guthruf et al., 1999). To mitigate the eutrophication, hypolimnetic withdrawal restoration has been applied in Lake Burgäschi since 1977, and the lake water has been monitored twice a year for more than 30 years for various parameters, such as $\mathrm{pH}$, oxygen content, phosphorus concentrations, and phytoplankton biomass. Despite a sharp decline in hypolimnetic phosphorus concentrations due to restoration, a high production of algal biomass continues today (GSA, 2007). Additionally, hypolimnetic oxic and anoxic condi- 
tions and the lake trophic state have been stabilized but not fundamentally improved (GBL, 1995; Guthruf et al., 2013).

\section{Materials and methods}

\subsection{Core collection and sampling}

In September 2017, two $75 \mathrm{~cm}$ long sediment cores (Burg17$\mathrm{B}$ and Burg17-C) were retrieved from the deepest point of Lake Burgäschi (water depth: $~ 31 \mathrm{~m})\left(47^{\circ} 10^{\prime} 8.6^{\prime \prime} \mathrm{N}\right.$, $07^{\circ} 40^{\prime} 5.3^{\prime \prime} \mathrm{E}$; coring site in Fig. 1c) using a UWITEC gravity corer. After the collection, the cores were stored in a dark, cold room $\left(\sim 4^{\circ} \mathrm{C}\right)$. After opening and splitting lengthwise, core half A of Burg17-B was continuously subsampled at $2 \mathrm{~cm}$ resolution from 0 to $60 \mathrm{~cm}$ for ${ }^{210} \mathrm{~Pb}$ and ${ }^{137} \mathrm{Cs}$ dating. The oxidized surface of core half B (Burg17-B) was visually described (Schnurrenberger et al., 2003) before nondestructive XRF core and HSI scanning. After the opening, one half of core Burg17-C was transferred immediately into a glove box with an anoxic atmosphere, where it was continuously subsampled at $2 \mathrm{~cm}$ resolution from 0 to $72 \mathrm{~cm}$. The fresh sediments from each sample slice were homogenized and used for sequential $\mathrm{P}$ extraction. After sampling for $\mathrm{P}$ extraction, the remaining sediment of the $2 \mathrm{~cm}$ slice was freezedried and homogenized for bulk element analyses.

\subsection{Chronology}

The chronology of the core Burg17-B is based on ${ }^{210} \mathrm{~Pb}$ and ${ }^{137} \mathrm{Cs}$ activity profiles. The freeze-dried and homogeneous samples were stored in a dry and dark place until analysis. The ${ }^{210} \mathrm{~Pb},{ }^{137} \mathrm{Cs}$, and ${ }^{226} \mathrm{Ra}$ radiometric activities were measured by gamma spectrometry at the University of Bern's Department of Chemistry and Biochemistry. A total of $1.3-5.1 \mathrm{~g}$ of the freeze-dried samples was encapsulated into polystyrene petri dishes $(68 \mathrm{~mm}$ O.D., $11 \mathrm{~mm}$ height; Semadeni, Ostermundigen, Switzerland) together with a polystyrene disk to fill in the headspace above the sample material, and the petri dishes were vacuum-sealed into gastight aluminum foil for equilibration. ${ }^{210} \mathrm{~Pb}(46.5 \mathrm{keV})$, ${ }^{241} \mathrm{Am}(59.5 \mathrm{keV}),{ }^{226} \mathrm{Ra}$ progenies ${ }^{214} \mathrm{~Pb}$, and ${ }^{214} \mathrm{Bi}(295.2$, 351.9 , and $609.3 \mathrm{keV})$, as well as ${ }^{137} \mathrm{Cs}(661.7 \mathrm{keV})$, were measured using a Broad Energy Germanium (BEGe) Detector (Canberra GmbH, Rüsselsheim, Germany). This system is composed of a high-purity germanium crystal with an area of $50 \mathrm{~cm}^{2}$, a thickness of $30 \mathrm{~mm}$, and a $0.6 \mathrm{~mm}$ thick carbon epoxy window, which shows high absolute full-energy peak efficiencies for close on-top geometries of more than $20 \%$ and $\sim 5 \%$ for ${ }^{210} \mathrm{~Pb}$ and ${ }^{137} \mathrm{Cs}$, respectively. Low integrated background count rates of $0.20 \mathrm{~s}^{-1}$ (energy range of 30-1800 keV) were achieved by the application of low-background materials, installation in the third underground floor ( $\sim 10 \mathrm{~m}$ of water-equivalent overburden), passive shielding (outside to inside: $10 \mathrm{~cm}$ low-background lead, $3 \mathrm{~mm}$ ancient lead with negligible ${ }^{210} \mathrm{~Pb}$ content, $2 \mathrm{~mm}$ cadmium), flushing of the shield interior with nitrogen gas, and an active anticosmic shield (plastic scintillator panels with a total area of $1 \mathrm{~m}^{2}$ mounted directly above the passive shielding). Supported ${ }^{210} \mathrm{~Pb}$ in each sample was assumed to be in equilibrium with the in situ ${ }^{226} \mathrm{Ra}$ (equilibration time: 4 weeks). Unsupported ${ }^{210} \mathrm{~Pb}$ activity was calculated by subtracting ${ }^{226} \mathrm{Ra}$ activity from total ${ }^{210} \mathrm{~Pb}$ activity level by level. The correction for the total missing inventory of unsupported ${ }^{210} \mathrm{~Pb}$ was in accordance with Tylmann et al. (2016).

The ${ }^{210} \mathrm{~Pb}$ chronology of core Burg17-B was determined using the constant rate of supply (CRS) model (Appleby, 2002), which accounts for variation in sediment accumulation rates. We tested two CRS models: the CRS-1 model was unconstrained (i.e., without reference points from the ${ }^{137} \mathrm{Cs}$ activity); the CRS-2 model was constrained with the chronologic marker of peak fallout from nuclear weapons testing in $1963\left({ }^{137} \mathrm{Cs}\right.$ and $\left.{ }^{241} \mathrm{Am}\right)$. Both models were then tested and validated with independent time markers at the onset of nuclear weapons testing in 1953/1954 and the Chernobyl accident in 1986/1987 (onset of ${ }^{137} \mathrm{Cs}$ and peak of ${ }^{137} \mathrm{Cs}$ and ${ }^{241} \mathrm{Am}$, respectively).

The two sediment cores (Burg 17-B and Burg 17-C) are visually very similar but show a length offset due to coring compaction of approximately $2-6 \mathrm{~cm}$ (Fig. S1 in the Supplement). The age-depth stratigraphy of the Burg17-C core was inferred from the dated core Burg17-B by visual stratigraphic correlation from high-resolution core pictures.

\subsection{Nondestructive geochemical methods}

Nondestructive X-ray fluorescence (XRF) core scanning was done using an Avaatech XRF core scanner (Richter et al., 2006) for semiquantitative element composition measurements at $0.5 \mathrm{~mm}$ resolution to capture relative elemental concentrations of the laminae. The core surface was smoothed and covered with a $4 \mu \mathrm{m}$ thick Ultralene foil prior to the analysis. Elements were measured using a rhodium anode and a $25 \mu \mathrm{m}$ Be window. The lighter elements (e.g., Al, Si, and P) were measured for $15 \mathrm{~s}$ count time at $10 \mathrm{kV}$ with $1500 \mathrm{~A}$ (no filter), while the heavier elements (e.g., $\mathrm{Mn}, \mathrm{Fe}$, and $\mathrm{Br}$ ) were exposed for $40 \mathrm{~s}$ at $30 \mathrm{kV}$ with $2000 \mathrm{~A}$ (thin Pd filter). Element intensities (semiquantitative concentrations) of the selected elements ( $\mathrm{Mg}, \mathrm{Si}, \mathrm{Al}, \mathrm{K}, \mathrm{Ti}, \mathrm{Rb}, \mathrm{P}, \mathrm{Fe}, \mathrm{Mn}, \mathrm{Ca})$ are expressed as count rates (counts per second, cps).

Following the methodology in Butz et al. (2015), hyperspectral-imaging (HSI) scanning was performed using a Specim, Spectral Imaging Ltd. single-core scanner equipped with a visual- to near-infrared-range (VNIR, 400$1000 \mathrm{~nm}$ ) hyperspectral line-scan camera (Specim PFD-CL$65-\mathrm{V} 10 \mathrm{E})$. Parameters were set for a spatial resolution of $\sim 70 \mu \mathrm{m}$ per pixel and a spectral sampling of $1.57 \mathrm{~nm}$ (binning of 2). Spectral end-members were determined using the "Spectral Hourglass Wizard" of the ENVI 5.5 software package (Exelis VIS ENVI, Boulder, Colorado). The relative absorption band depth (RABD) index calculation was 
performed following the method in Schneider et al. (2018). However, based on the spectral end-members (Fig. S2), we used the absorption feature between the wavelengths R590 and R765 (590-765 nm), i.e., RABD $590-765$. Butz et al. (2017) and Schneider et al. (2018) revealed that this index is well calibrated to absolute green-pigment (chlorophyll $a+$ pheophytin $a$ ) concentrations in sediments. The sediments in Lake Burgäschi are mostly laminated and organic-rich (van Raden, 2012), which indicates that the sediments are anoxic, bioturbation is absent, and sedimentary pigments are well preserved (Reuss et al., 2005). Therefore, in our study, the relative concentrations of green pigments inferred from $\mathrm{RABD}_{590-765}$ index values provide a semiquantitative reconstruction of lake primary productivity (total algal abundance) at subannual resolution and are suggested to reflect the trophic-state evolution of Lake Burgäschi.

\subsection{Phosphorus fractionation scheme and bulk element analyses}

The $\mathrm{P}$ fractionation extraction protocol (Fig. S3) principally follows the four-step extraction protocol in Tu et al. (2019a). In addition, we added the last extraction step from Lukkari et al. (2007) to determine refractory organic P (F5). This P fraction (F5) is practically biologically unavailable and subject to permanent $\mathrm{P}$ burial. The first four fractions are $\mathrm{NaCl}$-total $\mathrm{P}$ (TP) (F1: loosely bound P), NaBD-TP (F2: redox-sensitive $\mathrm{Fe}$ - and Mn-bound P), NaOH-TP (F3: Al- and Fe-bound P), and HCl-TP (F4: Ca-bound P) (Tu et al., 2019a), whereby $\mathrm{NaCl}-\mathrm{TP}, \mathrm{NaBD}-\mathrm{TP}$, and $\mathrm{NaOH}-\mathrm{TP}$ fractions together are considered to be relatively labile $\mathrm{P}$ fractions because they may release $\mathrm{P}$ back to the water column in anoxic or high$\mathrm{pH}$ environments (Rydin, 2000). The HCl-TP and refractory organic $\mathrm{P}\left(\right.$ ref. $\mathrm{P}_{\mathrm{o}}$ ) fractions are classified as relatively stable or refractory $\mathrm{P}$ fractions. Total $\mathrm{P}$ in sediments was obtained from the sum of the five $\mathrm{P}$ fractions. The $\mathrm{P}$ in extract samples was measured by inductively coupled plasma mass spectroscopy $(7700 \times$ ICP-MS) (Agilent Technologies, Germany) after dilution with nitric acid $\left(\mathrm{HNO}_{3}\right)$ to reach a final $\mathrm{HNO}_{3}$ concentration of $1 \% v / v$.

Concentrations of total carbon (TC), total nitrogen (TN), and total sulfur (S) in sediment samples were determined using an Elementar vario EL cube elemental analyzer. Total inorganic carbon (TIC) content was calculated by multiplying loss on ignition at $950^{\circ} \mathrm{C}\left(\mathrm{LOI}_{950}\right.$, following the method proposed by Heiri et al., 2001) by 0.273 , i.e., the ratio of the molecular weight of $\mathrm{C}$ and $\mathrm{CO}_{2}$. Total organic carbon (TOC) content was calculated using the equation TOC $=\mathrm{TC}-\mathrm{TIC}$. Sediment dry bulk density and water content were determined using wet mass $(\mathrm{g})$, dry mass $(\mathrm{g})$, and wet volume $\left(\mathrm{cm}^{3}\right)$ following the method in Håkanson and Jansson (2002).

\subsection{Data analyses}

Multivariate statistical analyses were performed with $\mathrm{R}$ version 3.4.2 (R Development Core Team, 2017). Prior to data analyses, $\mathrm{RABD}_{590-765}$ index values $(70 \mu \mathrm{m}$ resolution) were aggregated to a spatial resolution of $0.5 \mathrm{~mm}$ (the spatial resolution of XRF data). Stratigraphically constrained incremental sum-of-squares clustering (CONISS; Grimm, 1987) was then performed on semiquantitative proxies (i.e., RADB $_{590-765}$ index and XRF element data) with R package "rioja" (Juggins, 2017). The number of significant clusters was determined with a broken-stick test (Bennett, 1996). A principal component analysis (PCA) was performed on the centered and standardized data of semiquantitative proxies using the "vegan" package (Oksanen et al., 2013). XRF element and RABD $590-765$ index values were averaged within the depth range of each sample taken from core Burg17-C for $P$ fractions. In order to identify the primary factors influencing the variations in sedimentary $\mathrm{P}$ fractions, a redundancy analysis (RDA) was performed on the centered and standardized dataset of $\mathrm{P}$ fractions (response variables) and other sediment geochemical parameters (explanatory variables) with the vegan package. In the RDA computation, the correlation matrix option was selected, and the scaling was conducted on a correlation biplot.

\section{Results}

\section{1 $\quad{ }^{137} \mathrm{Cs}$ and ${ }^{210} \mathrm{~Pb}$ chronology}

The two distinctive peaks of ${ }^{137} \mathrm{Cs}$ in sediment profiles are detected at 31 and $15 \mathrm{~cm}$ depths (Fig. 2b), corresponding to the 1963 and 1986 major fallout events, respectively (Appleby, 2002). Furthermore, ${ }^{241} \mathrm{Am}$ activity peaks at the same depths (Fig. 2b) confirm that the 1963 and $1986{ }^{137}$ Cs peaks were due to atmospheric fallouts (Michel et al., 2001). The first traces of ${ }^{137} \mathrm{Cs}$ occur at $37 \mathrm{~cm}$ depth, indicating the first widely detectable fallout from atmospheric nuclear testing in 1953/1954 (Pennington et al., 1973).

The ${ }^{210} \mathrm{~Pb}$ activity in core Burg17-B shows a relatively monotonic decrease down to a sediment depth of $17 \mathrm{~cm}$. Further down, larger variations are found (Fig. 2a). The ${ }^{210} \mathrm{~Pb}$ and ${ }^{226} \mathrm{Ra}$ activities do not reach equilibrium; unsupported ${ }^{210} \mathrm{~Pb}$ activity in the oldest sample $(59 \mathrm{~cm})$ is still above the limit of detection $\left(14.0 \pm 6.8 \mathrm{~Bq} \mathrm{~kg}^{-1}\right)$. The observed cumulative inventory of unsupported ${ }^{210} \mathrm{~Pb}$ is $2941 \mathrm{~Bq} \mathrm{~m}^{-2}$. We corrected this value (missing inventory correction; Tylmann et al., 2016) by applying an exponential equation using the lowermost values of cumulative dry mass and unsupported ${ }^{210} \mathrm{~Pb}$ activity between 8 and $60 \mathrm{~cm}$ depths. As a result, a correction value of $125.2 \mathrm{~Bq} \mathrm{~m}^{-2}$ (missing inventory) is added to the final total unsupported ${ }^{210} \mathrm{~Pb}$ inventory $\left(3066 \mathrm{~Bq} \mathrm{~m}^{-2}\right.$ ).

The CRS-2 model (constrained through 1963) shows a better agreement with the independent ${ }^{137} \mathrm{Cs}$ markers from 


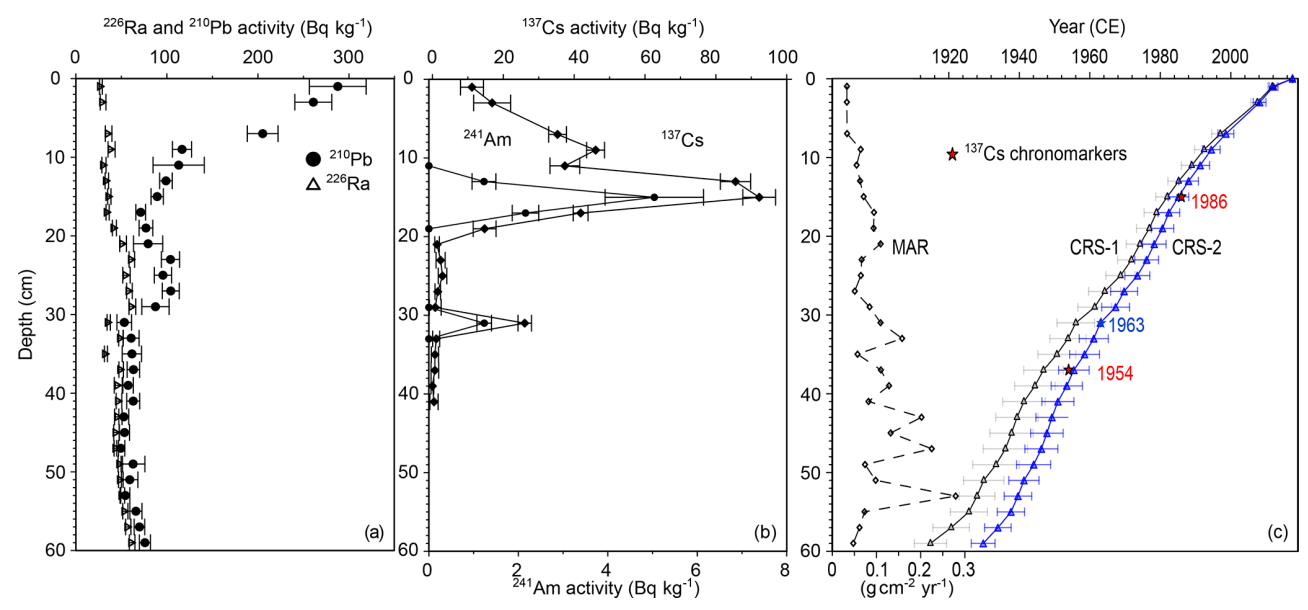

Figure 2. (a) Total ${ }^{210} \mathrm{~Pb},{ }^{226} \mathrm{Ra}$, and (b) ${ }^{137} \mathrm{Cs}$ and ${ }^{241} \mathrm{Am}$ activity concentration profiles in sediment core Burg17-B from Lake Burgäschi; (c) the comparison of different ${ }^{210} \mathrm{~Pb}$ CRS models: unconstrained CRS-1 model and constrained CRS-2 model for 1963; the mass accumulation rates (MARs) are obtained from the CRS-2 model.

1953/1954 and 1986/1987 than the CRS-1 model (Fig. 2c). Therefore, CRS-2 model results were chosen for determining the age-depth profile and sediment mass accumulation rates (MARs) of core Burg17-B. The sediment at a depth of $59 \mathrm{~cm}$ dates back to $\sim 1930$. The extrapolated mean year of origin at a depth of $61 \mathrm{~cm}$ is $\sim 1926$, calculated using the mean sediment accumulation rate between 54 and $60 \mathrm{~cm}\left(2 \mathrm{yr} \mathrm{cm}^{-1}\right)$.

\subsection{Sediment lithology, green pigments (RABD 590-765 index), and XRF element records}

Four sediment facies (I to IV, Figs. 3 and 4a) are identified based on visual classification and the CONISS analysis results of XRF element intensities.

In Zone I $(75.4-61 \mathrm{~cm}$; prior to $\sim 1926)$, the sediments consist of visible thin brown-to-reddish laminae (Mnand $\mathrm{Fe}$-rich). Green-pigment concentrations inferred from RABD $590-765$ index values show a homogenous distribution with the lowest values within the sediment profile (Fig. 4d). $\mathrm{Fe} / \mathrm{Mn}$ ratios vary within very low values (mostly below 10 ). The $\mathrm{Mn}, \mathrm{Fe}, \mathrm{P}$, and $\mathrm{Fe} / \mathrm{Ti}$ values show high levels with large variability. Extremely low $\mathrm{Ca}$ amounts are noted in this zone.

In Zone II (61-34cm; 1926-1960), the sediments are dark gyttja, partly laminated with light Ca-rich layers. Greenpigment concentrations slightly increase yet still show little variability. A sharp increase in green-pigment concentrations occurs at $60 \mathrm{~cm}$, and the first two local peaks near $55 \mathrm{~cm}$ ( 1938) and $48 \mathrm{~cm}$ (1945) are notable. $\mathrm{Fe} / \mathrm{Mn}$ ratios remain at slightly higher values than in Zone I. The Mn, Fe, and P contents and $\mathrm{Fe} / \mathrm{Ti}$ values all decline to low levels and remain relatively stable. Ca counts increase gradually over the whole Zone II.

In Zone III (34-21.5 cm; 1960-1977), the sediments are mostly characterized by brown-to-reddish laminations (Mnand Fe-rich) with thicker and more distinct laminae con- tacts than in Zone I. Green-pigment concentrations exhibit much higher values with positive trends, intensified variability, and several maxima (seasonal algal blooms). Fe/Mn ratios first drop in the lower part $(34-27 \mathrm{~cm})$ and then continue to increase upward to the top part of Zone III. Fe, Mn, P, and $\mathrm{Fe} / \mathrm{Ti}$ values show generally opposing trends to $\mathrm{Fe} / \mathrm{Mn}$ ratios. Ca content is elevated during this period relative to Zones I and II.

In Zone IV (21.5-0 cm; 1977-2017), the sediments exhibit a clear laminated structure with much more pronounced light calcite layers. The laminations are characterized by a regular succession of light calcite layers (Ca-rich) and dark organic-rich layers (Fig. S4). Green-pigment concentrations display the highest levels with large fluctuations and reach distinct local maxima at $18 \mathrm{~cm}(1981), 15 \mathrm{~cm}(1985), 13 \mathrm{~cm}$ (1987), $12 \mathrm{~cm} \mathrm{(1988),} \mathrm{and} 8 \mathrm{~cm}$ (1997) depths (Fig. 4d). $\mathrm{Fe} / \mathrm{Mn}$ ratios are at similarly high values as in Zone II, yet with more variability. The $\mathrm{Fe}, \mathrm{Mn}$, and $\mathrm{P}$ element counts and $\mathrm{Fe} / \mathrm{Ti}$ all show constantly very low values. The $\mathrm{Ca}$ amounts are the highest in the profile and show considerable variability.

Two principle components, PC1 and PC2, were shown to be significant using a broken-stick model. They explain $\sim 35 \%$ and $\sim 30 \%$ of the total variance in the dataset, respectively (PCA biplot; Fig. S5). PC1 has strong positive loadings for the terrigenous elements $(\mathrm{K}, \mathrm{Ti}, \mathrm{Rb}$, etc.; Figs. 3 and S6) and thus represents mainly erosional processes related to allochthonous inputs. PC2 has strong positive loadings for redox-sensitive elements ( $\mathrm{Fe}, \mathrm{Mn}$ ), $\mathrm{P}$, and $\mathrm{Fe} / \mathrm{Ti}$ but negative loadings for $\mathrm{Ca}, \mathrm{Fe} / \mathrm{Mn}$ ratios, and green-pigment index values. Therefore, PC2 reflects changes in redox conditions of hypolimnetic water and lake primary productivity. The results of additional PCA analyses zone by zone (Fig. S7b) show that Mn, Fe, and P were mostly independent of terrigenous elements (in Zones I to III); however in 


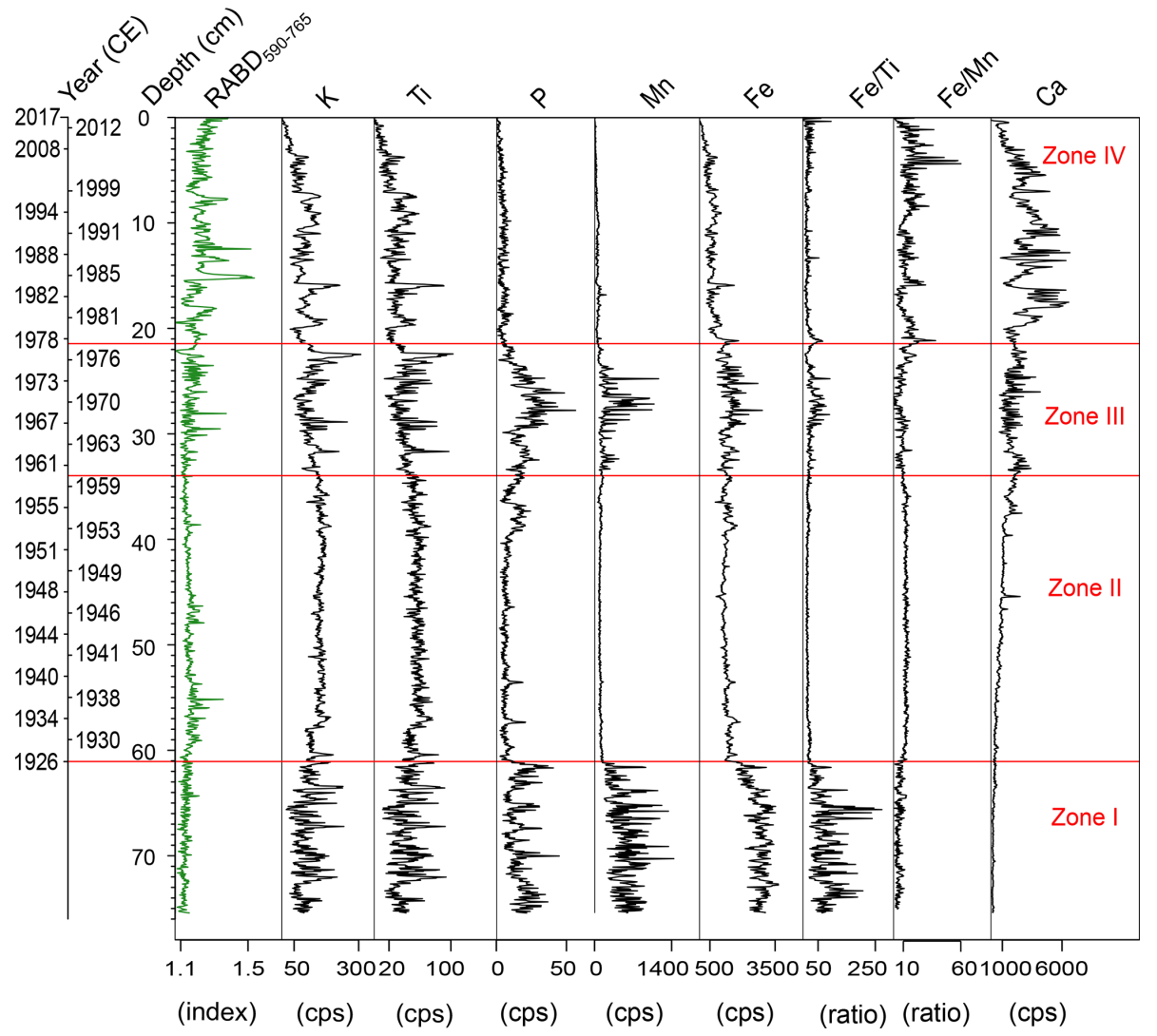

Figure 3. Stratigraphic records of HSI-inferred green pigments (RABD $590-765)$ and XRF data in sediments of core Burg17-B. Elemental counts are represented in cps (counts per second). The red horizontal lines separate the four significant clusters retrieved by the CONISS analysis (color figure online).

Zone IV, Mn, Fe, and P become correlated with the terrigenous elements. The vertical profile of XRF P matches very well with the changes in total $\mathrm{P}$ concentrations in sediments (Fig. S8). It reveals that XRF P data can reliably represent qualitative variations of total $\mathrm{P}$ concentrations in sediment profiles of Lake Burgäschi.

\subsection{Bulk elements and $P$ fractions in sediment profiles}

Sediment TIC, TOC, the TOC/TN ratio, $\mathrm{S}$, and $\mathrm{P}$ fractions also show distinctive features along the four stratigraphic zones (Fig. 5). From the upper part of Zone I (65.2-61 cm; 1926) to Zone IV, TIC shows a similar pattern to the XRF Ca content (Figs. 3 and 5), suggesting that TIC is mostly present in the form of $\mathrm{CaCO}_{3}$. Over the whole profile, TOC/TN ratios are within the range of $9-11$. TOC and TOC/TN ratios exhibit mostly similar patterns from Zone I to Zone III. By contrast, total sulfur (S) content displays a different pattern, showing very low values in Zones I and II (mean $\sim 0.5 \%$ ) and a substantial increase in Zones III and IV.

The concentrations of labile $\mathrm{P}$ fractions (i.e., $\mathrm{NaCl}-\mathrm{TP}$, $\mathrm{NaBD}-\mathrm{TP}$, and $\mathrm{NaOH}-\mathrm{TP}$ ) and total $\mathrm{P}$ have a similar trend over the whole profile (Figs. 5 and 6a). They all display rather large values within the upper part of Zone I and generally decreased values in Zone II. In Zone III, the values increase to peaks at $\sim 25 \mathrm{~cm}$ depth but sharply decrease to the lowest values in the upper boundary of Zone III and throughout Zone IV. HCl-TP and ref. $\mathrm{P}_{\mathrm{o}}$ fractions vary differently compared with the other fractions. Low contents of the HCl-TP fraction are observed in Zones I and II. The HCl-TP fraction has a pattern that is rather similar to that of labile $\mathrm{P}$ fractions in Zone III, but then it remains at high levels in Zone IV. Ref. $\mathrm{P}_{\mathrm{O}}$ fraction contents show relatively stable values from Zone I to Zone II, followed by a gradual rise in Zone III and in the upper part of Zone IV. The net burial rates (NBRs) of the P fraction since 1934 (Fig. S9) show similar trends to the $\mathrm{P}$ fraction concentrations (Fig. 5) (because sedimentation MARs are rather constant in core Burg17-C; Fig. S9) except for the $\mathrm{Ca}-\mathrm{P}$ and ref. $\mathrm{P}_{\mathrm{o}}$ fractions with a decreasing NBR throughout the Zone IV.

Regarding the $\mathrm{P}$ composition in sediment profiles (Fig. 6, absolute and relative amounts), from Zone I to Zone III $(65.2-21.5 \mathrm{~cm})$ the NaBD-TP fraction is the most important $\mathrm{P}$ form, representing $\sim 50 \%$ of total $\mathrm{P}$, followed by the $\mathrm{NaOH}-\mathrm{TP}$ fraction. However, in Zone IV (depth above 


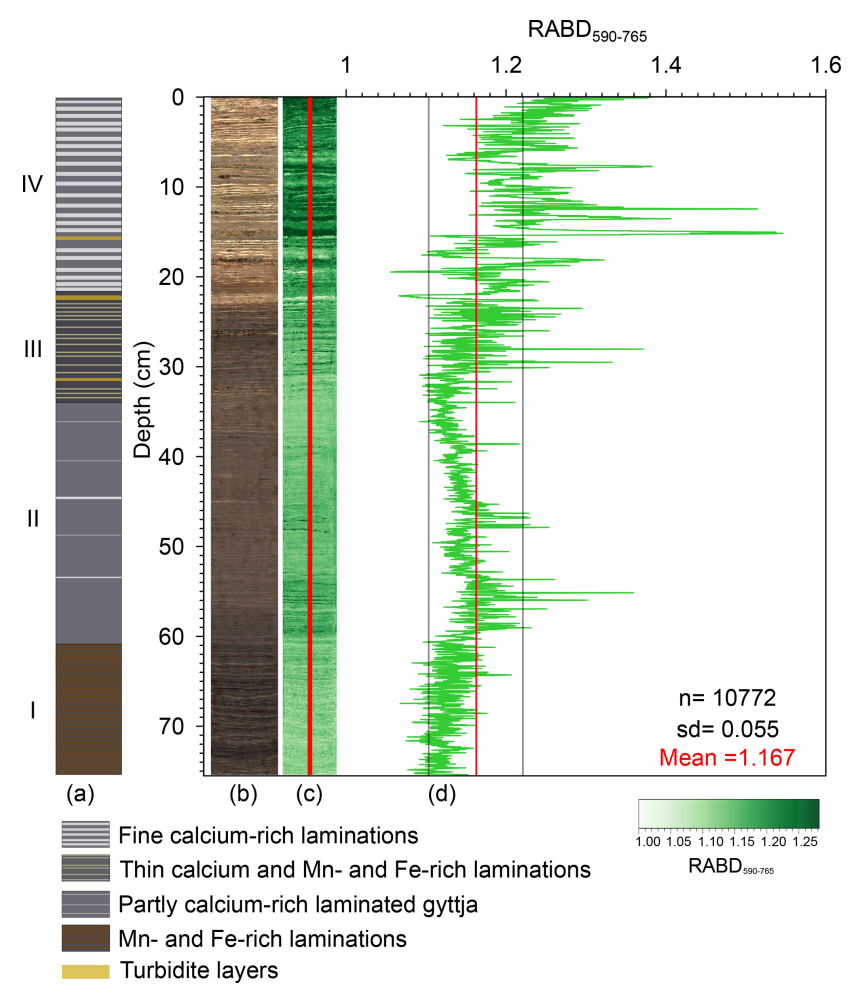

Figure 4. (a) Lithological description of the Burg17-B sediment core. The intensities of $\mathrm{Ca}, \mathrm{Fe}$, and $\mathrm{Mn}$ in each unit were inferred from XRF element counts in Fig. 3; yellow colors highlight the turbidite layers identified from the XRF peaks of siliciclastic elements, e.g., K, Ti, and Rb. (b) RGB contrast-enhanced sediment core picture. (c) The map of the spectral index RABD $590-765$ (i.e., green pigments) distribution and (d) the graphic output of the RABD 590-765 spectral index within the boundary of the red lines, (c) which shows the $2 \mathrm{~mm}$ wide sampling range. The red line in (d) indicates the mean index value and the gray lines represent 1 deviation (SD). The color bar represents the index values of the distribution map (color figure online). $n$ is the number of rows of the RABD $590-765$ index map.

$\sim 21.5 \mathrm{~cm}), \mathrm{HCl}-\mathrm{TP}$ becomes the main $\mathrm{P}$ fraction $(\sim 39 \%$ of total P) over NaBD-TP ( 30\% of total P).

The relationships between response variables and explanatory variables are visible on the redundancy analysis (RDA) biplot (Fig. 7). In most cases, these relationships correspond well with the results of the Spearman rank correlation test (Fig. S10). The relatively labile P fractions $(\mathrm{NaCl}-$ TP, NaBD-TP, and $\mathrm{NaOH}-\mathrm{TP}$ ) and total $\mathrm{P}$ in sediments are strongly positively correlated with redox-sensitive elements (Fe and $\mathrm{Mn}$ ) and autochthonous $\mathrm{Fe}$ (Fe/Ti). However, these $\mathrm{P}$ fractions are negatively related to the hypolimnetic oxygenation proxy (Fe/Mn ratios) and, to some extent, to lake productivity indicators (green pigments, XRF Ca, and TIC). $\mathrm{HCl}-\mathrm{TP}$ and ref. $\mathrm{P}_{\mathrm{O}}$ fractions are positively correlated. However, only the $\mathrm{HCl}-\mathrm{TP}$ fraction has close positive relationships with lake productivity indicators.

\section{Discussion}

\subsection{Trophic-state evolution of Lake Burgäschi}

Four main phases of different lake trophic levels (based on $\mathrm{RABD}_{590-765}$ index values) have been distinguished since the early 1900s, as summarized in Figs. 8 and S11. During the period prior to $\sim 1926$ in Zone I, the lowest greenpigment index values reflect low lake primary productivity. In the early 1900s, agricultural impacts around the catchment area of Lake Burgäschi were not prominent (Guthruf et al., 1999). It can be expected that the lake received low nutrient loads from catchment drainage during this period. Lake Burgäschi is classified as naturally oligotrophic based on morphometric parameters (LAWA, 1998) and as naturally mesotrophic according to Binderheim-Bankay (1998). Therefore, at the times of Zone I, Lake Burgäschi was likely oligo- to mesotrophic.

The transition to Zone II ( 1926-1960) was marked by generally increased sedimentary green-pigment concentrations and $\mathrm{CaCO}_{3}$ content (Figs. 3, 4d, and 5), indicating enhanced lake primary productivity. The slightly decreased TOC/TN ratio also suggests a rise in the proportion of autochthonous organic matter (Meyers and Ishiwatari, 1993). The first two algal blooms (peaks of green-pigment index; Fig. 4d) imply a very likely mesotrophic to eutrophic state of the lake. Indeed, the study of von Büren (1949) revealed that between 1943 and 1945, the trophic state of Lake Burgäschi had already shifted between mesotrophic and eutrophic. Interestingly, the water table lowering between 1943 and 1945 (Guthruf et al., 1999) with related enhanced drainage of intensive agricultural fields and meadows (von Büren, 1949) did not seem to have had an immediate impact on lake primary productivity (Fig. 3).

In Zone III ( 1960-1977), continuously increasing green-pigment concentrations indicating several algal bloom events and intensified $\mathrm{CaCO}_{3}$ precipitation (TIC) and sulfur (S) content in sediments (Figs. 4a and 5) are in agreement with the findings from other eutrophic lakes (Holmer and Storkholm, 2001; Bonk et al., 2016; Schneider et al., 2018).

During Zone IV (1977-2017), we interpret that Lake Burgäschi was subjected to highly eutrophic conditions based on constantly high green-pigment index values and multiple prominent algal blooms (Fig. 3). Low and decreasing TOC/TN ratio values $(<10)$ in this zone suggest a dominant source of organic matter in sediments from aquatic primary production, which has been interpreted as a signal of eutrophic waters (Enters et al., 2006). Our interpretation is further supported by high chlorophyll $a$ concentrations in surface waters $\left(>8 \mu \mathrm{g} \mathrm{L}^{-1}\right.$; GSA, 2007) and the dominance of blue-green algae in the phytoplankton biomass from 1977 to 1992, which characterized Lake Burgäschi as highly eutrophic (GBL, 1995; Guthruf et al., 2013). 


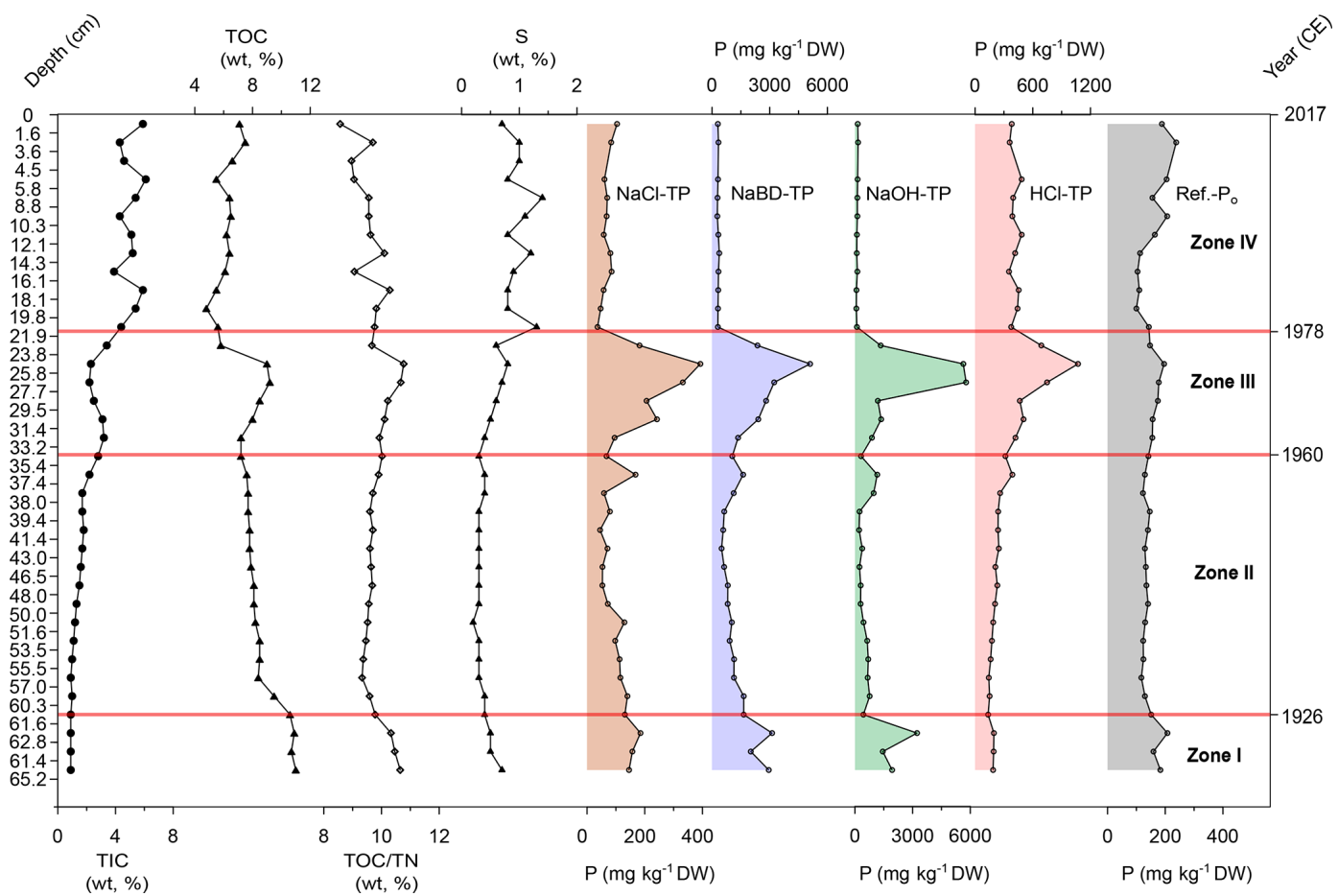

Figure 5. The stratigraphy of total inorganic carbon (TIC), total organic carbon (TOC), sulfur (S) content, the TOC/TN ratio, and five phosphorus fractions in sediments of Lake Burgäschi. The $y$ axis (left) refers to the sediment depth of core Burg17-B. The red horizontal lines separate the significant CONISS zones as in Fig. 3. The secondary $y$ axis (right) indicates approximate ages of sediments inferred from the Burg17-B core chronology.
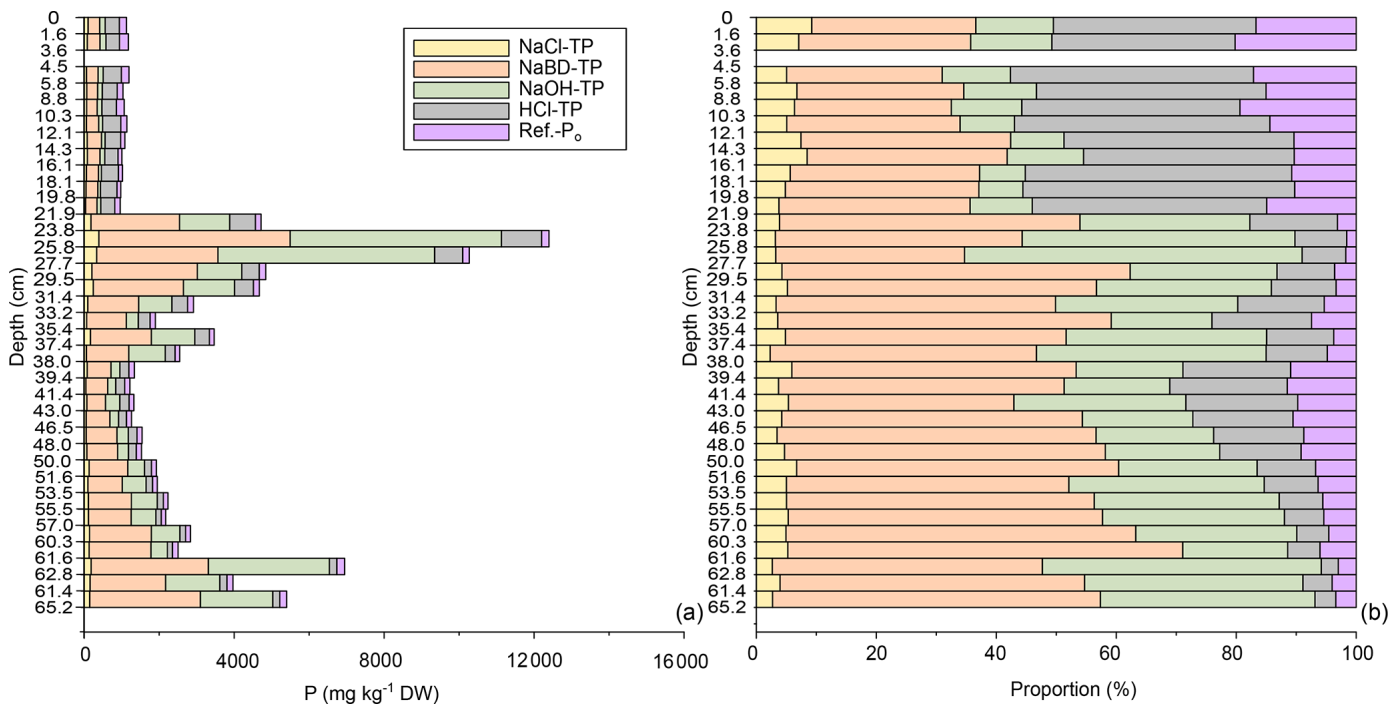

Figure 6. Vertical profile of (a) P fraction concentrations and (b) their proportions of total $\mathrm{P}$ in sediments. The $y$ axis (left) refers to the sediment depth of core Burg17-B. Note that the sample between 3.6 and $4.5 \mathrm{~cm}$ depth was removed from the dataset because the values were extremely higher than any sample data (data not shown), which is abnormal according to XRF P counts at the corresponding depth (Fig. S8b). We attributed this to the result of contamination during the sample measurements. 


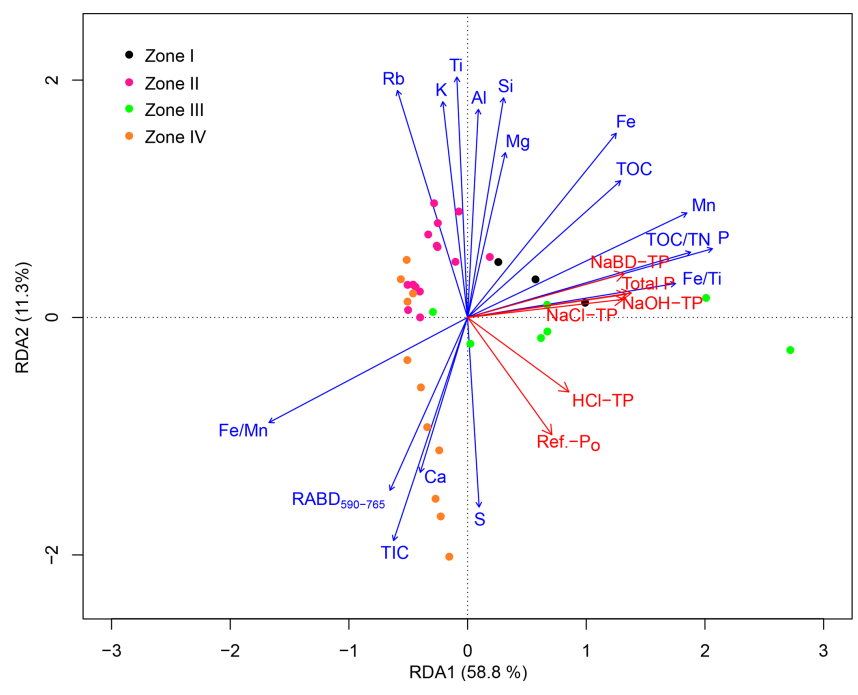

Figure 7. RDA biplot displaying correlation between response variables (P fraction dataset; red arrows) and explanatory variables (green pigments and other geochemical records; blue arrows). The colored points represent data points of individual cluster zones in Figs. 3, 5, and S6.

\subsection{Reconstruction of hypolimnetic oxygenation regimes of Lake Burgäschi}

A large number of studies have used the proxy of $\mathrm{Fe} / \mathrm{Mn}$ ratios in sediments to reconstruct past water oxygenation and mixing regimes of the lake, such as Mackereth (1966), Frugone-Álvarez et al. (2017), and Żarczyński et al. (2019). However, this proxy and its interpretation are limited to cases in which the annual cycle of $\mathrm{Fe}$ and $\mathrm{Mn}$ deposition in lakes is mostly driven by redox changes in the hypolimnion and related diagenetic processes in surface sediments instead of driven by terrestrial inputs (Boyle, 2001; Naeher et al., 2013). In Zones I to III in Lake Burgäschi, Mn and Fe varied mostly independently of erosion indicators as shown in Fig. S7b. Furthermore, van Raden (2012) has revealed that the presence of Mn-rich laminae in sediments of Lake Burgäschi can indicate frequent short-term wind-induced mixing events in the lake. Therefore, we suggest that the deposition of $\mathrm{Fe}$ and Mn during these three zones was mainly controlled by inlake processes. The proxy of XRF-inferred $\mathrm{Fe} / \mathrm{Mn}$ ratios together with Mn precipitation in sediments reliably tracks past changes of hypolimnetic oxygenation of Lake Burgäschi.

In Zone I (prior to 1926), the sediments feature wellpreserved, $\mathrm{Mn}$ - and Fe-rich laminations and very low $\mathrm{Fe} / \mathrm{Mn}$ ratios (Figs. 3 and 4a), suggesting that the lake hypolimnion was seasonally well oxygenated. A similar occurrence of visible Mn- and Fe-rich laminae in sediments was also reported by Rey et al. (2017) in Lake Burgäschi and in other lakes, for example, Lake of the Clouds in the US (Anthony, 1977), Lake Cadagno in the Swiss Alps (Wirth et al., 2013), and Lake Żabińskie in Poland (Żarczyński et al., 2018). They revealed that the red-orange, Mn-rich layers mostly consist of authigenic rhodochrosite $\left(\mathrm{MnCO}_{3}\right)$ that was formed when Mn-rich anoxic bottom waters were mixed with oxygenated surface waters for short intervals. The preservation of this Mn-rich layer is only possible when its sedimentation process exceeds the release process under anoxic hypolimnetic conditions (Stevens et al., 2000). Therefore, during this period, short-term mixing events and associated oxygenation may have occurred under overall stratified or anoxic conditions in the hypolimnion.

In Zone II ( 1926-1960), the higher Fe/Mn ratios and very low $\mathrm{Mn}$ and autochthonous $\mathrm{Fe}(\mathrm{Fe} / \mathrm{Ti})$ amounts are interpreted as the results of stable anoxic hypolimnetic waters. The formation and preservation of $\mathrm{Fe}$ and $\mathrm{Mn}$ oxides in sediments are largely prevented under long-term stratification and reducing conditions (Stevens et al., 2000). The lake most likely developed anoxic hypolimnetic conditions with yearly incomplete or missing circulation in the hypolimnion.

In Zone III (1960-1977), overall decreased Fe/Mn ratios combined with reappearing $\mathrm{Mn}$ - and Fe-rich laminations reflect better short-term oxic conditions in hypolimnetic waters than in Zone II. However, from 1970 to 1977, $\mathrm{Fe} / \mathrm{Mn}$ ratios gradually increased (Fig. 3), which points to less oxic conditions in the hypolimnion. This seems to be related to synchronously progressive lake eutrophication (see Sect. 5.1). Higher primary productivity and strengthened anoxia in the hypolimnion are commonly observed in stratified lakes (Giguet-Covex et al., 2010; Mikomägi et al., 2016). Higher lake primary productivity increases high-rate aerobic degradation of organic matter and, consequently, oxygen depletion in the hypolimnion and sediments (Gächter and Müller, 2003; Nürnberg, 2007).

Finally, in Zone IV (1977-2017) the Fe/Mn ratio proxy is no longer valid for indicating a hypolimnetic oxygenation regime, as suggested by predominantly terrestrial sources of sediment Fe and Mn (Fig. S7b). Nevertheless, the wellpreserved laminated sediments during this period are a clear sign of absent benthic bioturbation and thus represent an indicator of generally strong anoxic conditions in hypolimnetic waters occurring simultaneously with a highly eutrophic period. According to the limnological monitoring data of Lake Burgäschi between 1978 and 2007 (GSA, 2007), the lake water was anoxic at depths below $20 \mathrm{~m}$ during the summerautumn stratification; even during winter overturn of most years, the lake water was not completely mixed.

\subsection{Phosphorus composition and factors controlling long-term $P$ fraction retention in sediments}

Prior to 1977 (i.e., Zones I-III), NaBD-TP (redox-sensitive $\mathrm{Fe}-$ and $\mathrm{Mn}$-bound $\mathrm{P}$ ) and $\mathrm{NaOH}-\mathrm{TP}$ (partly nonreducible Fe-oxide-bound $\mathrm{P}$ ) fractions were the primary $\mathrm{P}$ forms in sediments of Lake Burgäschi (Figs. 6 and 8). This seems to compare well with the study of Moosmann et al. (2006), who suggested that sediment $\mathrm{Fe}$ content controls $\mathrm{P}$ reten- 

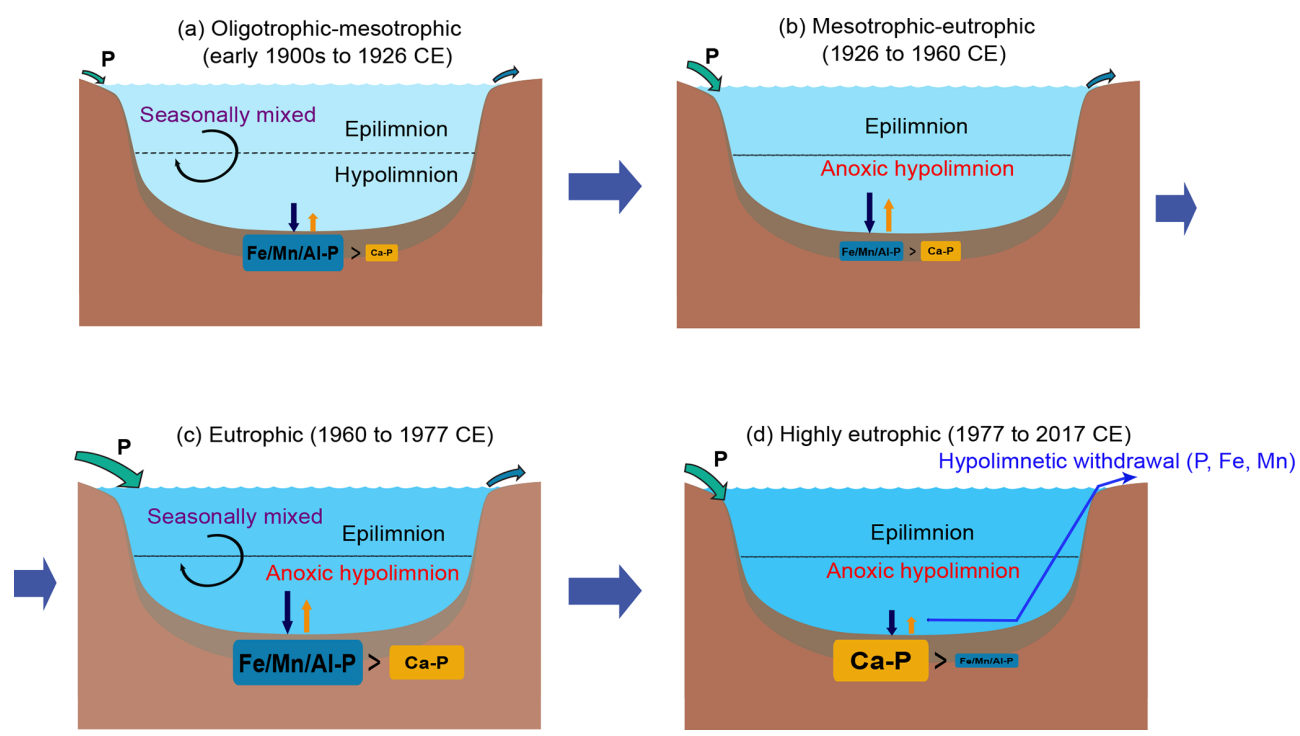

Figure 8. Conceptual diagram, summarizing the inputs/outputs of phosphorus (P), hypolimnetic withdrawal restoration, lake trophic levels, mixing regime, and phosphorus $(\mathrm{P})$ fraction retention in sediments of Lake Burgäschi during four stages/zones. Note that, overall, the illustrated sizes of $\mathrm{P}$ fractions (Fe, Mn, Al-P, and $\mathrm{Ca}-\mathrm{P}$ ) among different stages indicate the relative amounts of $\mathrm{P}$ fractions in sediments.

tion in sediments of the Swiss Plateau lakes. However, after $\sim 1977$, we observed a change to predominantly Ca-P (apatite $\mathrm{P}$ ), occurring concurrently with the operation of hypolimnetic withdrawal restoration. This clear pattern in sedimentary $\mathrm{P}$ fraction change can be largely attributed to this restoration measure. The hypolimnetic withdrawal treatment in Lake Burgäschi removes not only hypolimnetic $\mathrm{P}$ but also dissolved metal ( $\mathrm{Al}, \mathrm{Fe}$, and $\mathrm{Mn}$ ) ions and thus leads to calcite as the main sorbent for $\mathrm{P}$ in upper waters and to an enhanced proportion of the $\mathrm{Ca}-\mathrm{P}$ fraction in sediments.

In spite of the effects of lake restoration on sedimentary $\mathrm{P}$ retention in Zone IV, the retention of total $\mathrm{P}$ and labile $\mathrm{P}$ fractions in the sediment profile was overall mainly controlled by autochthonous $\mathrm{Fe}(\mathrm{Fe} / \mathrm{Ti}), \mathrm{Mn}$, and hypolimnetic oxygenation proxy $\mathrm{Fe} / \mathrm{Mn}$ ratios, as shown by the results of the RDA analysis (Fig. 7). Our results support the previous suggestion that long-term permanent sediment $\mathrm{P}$ retention is largely limited by the sediment's binding capacity under anoxic conditions (Moosmann et al., 2006; Hupfer and Lewandowski, 2008), which, specifically in our case, is determined by redox-sensitive elements (autochthonous $\mathrm{Fe}$ and $\mathrm{Mn})$ preserved in sediments. These findings are discussed in the context of each cluster zone as follows: during Zone I and Zone III, when the hypolimnion had better seasonally oxic conditions (see Figs. 8 and S11), the increased retention of $\mathrm{Mn}$ and $\mathrm{Fe}$ and labile $\mathrm{P}$ fractions occurred simultaneously (Figs. 3 and 5). This phenomenon might be caused by efficient $\mathrm{P}$ trapping in $\mathrm{Mn}$ - and Fe-enriched layers. It has been suggested that the formation of laminated $\mathrm{Mn}$ - and $\mathrm{Fe}$ enriched layers could serve as a protective cap to reduce $\mathrm{P}$ release from surface sediment layers to the anoxic hypolimnion (Żarczyński et al., 2018), which thus can help improve P re- tention within these sedimentary layers. In Zone II, small amounts of labile $\mathrm{P}$ fractions might result from decreased Pbearing solid phases (Mn and Fe minerals) in sediments under anoxic conditions in the hypolimnion (see higher Fe/Mn ratios in Sect. 5.2 and Fig. S11). However, in Zone IV, we observed the lowest retention and NBR of total P and labile $P$ fractions in recent sediments (Figs. 5 and S9). We interpret this as a combined result of eutrophication-induced hypolimnetic anoxia and hypolimnetic withdrawal since 1977, whereby P-rich hypolimnetic water is discharged out of the lake. On the one hand, under stable anoxic conditions in the hypolimnion caused by strong eutrophication, reduced $\mathrm{Mn}$ and Fe preservation (Fig. 3) suggests a low capacity of permanent $\mathrm{P}$ trapping within the anoxic sediments. On the other hand, hypolimnetic withdrawal restoration in Lake Burgäschi has substantially reduced hypolimnetic $\mathrm{P}$ concentrations by a factor of 5-6 since 1978 (Fig. S11; GSA, 2007) and has reduced MARs (Figs. 2c and S9). This indicates a concomitant decrease in sediment $\mathrm{P}$ release to the hypolimnion and $\mathrm{P}$ sedimentation to the water-sediment interface (gross sedimentation of P) as well. Consequently, decreased total P concentrations and total P NBRs in sediments were observed (Figs. 6a and S9). The reduction in total $\mathrm{P}$ content in upper sediments caused by hypolimnetic withdrawal was also reported from Lake Kortowskie in Poland (Dunalska et al., 2007). Moreover, our findings confirm that this restoration is an effective method for reducing sediment $\mathrm{P}$ release potential, as indicated by a considerably decreased NBR of labile P fractions in upper sediments (Fig. S9).

In the whole sediment profile, $\mathrm{HCl}-\mathrm{P}$ and ref. $\mathrm{P}_{\mathrm{O}}$ fractions had mainly autochthonous origins and were mainly controlled by in-lake processes rather than by clastic inputs (e.g., 
apart from molasses sandstone), as indicated by absent positive correlations between the two fractions and detrital elements such as $\mathrm{Ti}, \mathrm{K}$, and $\mathrm{Al}$ (Fig. 7). To a large extent, $\mathrm{HCl}-$ $\mathrm{P}$ (i.e., $\mathrm{Ca}-\mathrm{P}$ ) fraction retention resulted from authigenic $\mathrm{CaCO}_{3}-\mathrm{P}$ precipitation and increased with higher eutrophic levels in Zones III and IV (Fig. 5 and Sect. 5.1). We interpret this as an incidence of biologically driven coprecipitation of $\mathrm{Ca}$ and $\mathrm{P}$ in highly productive lakes. The phenomenon of $\mathrm{Ca}-\mathrm{P}$ coprecipitation has been observed and studied in many calcareous lakes (Dittrich and Koschel, 2002; Whitehouse, 2010) and is assumed to be responsible for the scavenging of dissolved $\mathrm{P}$ from surface waters of eutrophic lakes (Hamilton et al., 2009). In addition, large amounts of $\mathrm{Ca}-\mathrm{P}$ in surface sediments (top $21 \mathrm{~cm}$ ) can act as potential negative feedback to eutrophication in Lake Burgäschi because the $\mathrm{Ca}-\mathrm{P}$ fraction is relatively stable in sediments and has a low potential for $\mathrm{P}$ release from surface sediments back to lake waters. Interestingly, $\mathrm{HCl}-\mathrm{P}$ fraction retention and NBRs in sediments of Zone IV were generally lower than in Zone III (Figs. 5 and S9) although the lake in Zone IV had relatively higher eutrophic levels (see Sect. 5.1 and Fig. S11). The pH in the hypolimnion of Lake Burgäschi varied between 7.0 and 7.5 according to the monitoring data in 1993, 2003, and 2013 (Guthruf et al., 2013). Therefore, the acid dissolution of $\mathrm{Ca}-\mathrm{P}$ in the hypolimnion and at the water-sediment interface is small and unlikely significant during Zone IV. The generally decreased retention and NBR of the $\mathrm{Ca}-\mathrm{P}$ fraction were seemingly related to hypolimnetic withdrawal, which has caused lower water P concentrations and MARs of sediments as discussed above. As a result, there are reductions in $\mathrm{CaCO}_{3}-\mathrm{P}$ coprecipitation in the epilimnion and consequently in $\mathrm{Ca}-\mathrm{P}$ net sedimentation in surface sediments. Overall, ref. $\mathrm{P}_{\mathrm{o}}$ fraction retention and the NBR in the sedimentary profile show less variability compared with other $P$ fractions (Figs. 5 and S9). Nevertheless, the lower NBR of the ref. $P_{o}$ fraction in the upper sediments $(\sim$ top $10 \mathrm{~cm})$ could be derived from the ongoing early degradation of fresh organic matter.

The interesting observation is that the water $P$ reductions caused by the hypolimnetic withdrawal in Lake Burgäschi (GSA, 2007; Nürnberg, 2007) have been ineffective in reducing algal blooms and curbing eutrophication. Similar findings were also reported from some lakes in Europe and the US (Kosten et al., 2012; Kolzau et al., 2014; Fastner et al., 2016). These authors have attributed this phenomenon to insufficient external P load reduction, higher water temperatures under global warming of the last few decades, and the light or nitrogen limitation of surface water phytoplankton. In Lake Burgäschi, phytoplankton growth in the trophic zone is more likely limited by $\mathrm{P}$ during the growth season after 1978 rather than by nitrogen (GSA, 2007) as the algaeavailable orthophosphate is almost completely used up in the epilimnion when the nitrate concentrations stay as high as $0.5-3 \mathrm{mg} \mathrm{NL}^{-1}$ in the upper $5 \mathrm{~m}$ of water (GBL, 1995). Hence, we suggest that, with the exception of nitrogen limitation of lake productivity, the factors mentioned above may also contribute to promoting persistently high primary productivity in Lake Burgäschi. But the main driver keeping productivity high are the continuously high external $\mathrm{P}$ loads from the lake catchment. During summer stratification, the high lake external $P$ load into the epilimnion primarily supports phytoplankton growth in the photic zone, which is not strongly influenced by hypolimnetic-P discharge and internal $\mathrm{P}$ loadings. From a management perspective, it is still critically important to focus on lowering external $\mathrm{P}$ loads in order to decrease primary production and eutrophication in seasonally stratified small, deep lakes, which are more likely to favor stable stratification during the phytoplankton growth season.

\section{Conclusion}

This study shows that in Lake Burgäschi, more than half of sediment $\mathrm{P}$ is buried in relatively labile $\mathrm{P}$ fractions $(\mathrm{Fe}, \mathrm{Mn}$, and $\mathrm{Al}-\mathrm{P}$ ), yet with a low potential for $\mathrm{P}$ release from these labile $\mathrm{P}$ fractions in deeper layers (below $\sim 21 \mathrm{~cm}$ ). Our results highlight the importance of hypolimnetic oxygenation and a mixing regime in controlling long-term $P$ retention and net burial rates of labile $P$ fractions in sediments of this small, deep lake. Irrespective of increasing lake primary productivity from the early 1900s to 1977 , the two periods of high sedimentary retention of total $\mathrm{P}$ and the labile $\mathrm{P}$ fraction occurred in Fe- and Mn-enriched laminae, which appears to be linked to seasonal mixing of the hypolimnion in the past. Importantly, the positive effects of hypolimnetic withdrawal in Lake Burgäschi were observed primarily in sediment $\mathrm{P}$ fraction data but not in the lake trophic state. The 40-year operation of hypolimnetic withdrawal has impoverished sedimentary $\mathrm{P}$, largely decreased net burial rates of labile $\mathrm{P}$ fractions (potential internal P loads) in particular, and increased the relative proportion of the stable $\mathrm{Ca}-\mathrm{P}$ fraction in the top sediment layers $(0-21 \mathrm{~cm})$. Nevertheless, the lake is currently still highly eutrophic. We attribute the delay of lake recovery primarily to still high nutrient input from the nearby or surrounding agricultural area into the lake trophic zone during stratification seasons. This study calls for consistently more effective measures to minimize external $P$ loadings from the catchment, such as optimizing fertilizer application practices and technical measures in the drainages.

Data availability. The data are available at PANGAEA at https://doi.org/10.1594/PANGAEA.908896 (Tu et al., 2019b).

Supplement. The supplement related to this article is available online at: https://doi.org/10.5194/bg-17-2715-2020-supplement.

Author contributions. LT helped with sample collection, analyzed the sediment, conducted data analysis, wrote the manuscript, and 
acquired most of the funding for the project. PZ helped with sediment core subsampling, conducted the hyperspectral-imaging (HSI) scanning, helped with XRF scanning, and substantially contributed to the data interpretation. SöS measured gamma spectroscopy radiometric activities, generated the data for chronology, and helped with data interpretation. RL conducted the XRF scanning and helped with data interpretation. MG designed the study, helped in discussing the results and editing the manuscript, and supervised the project. All authors commented on the manuscript.

Competing interests. The authors declare that they have no conflict of interest.

Acknowledgements. We thank Stamatina Makri and Andre F. Lotter for their help during the fieldwork. We thank Irene Brunner, Patrick Neuhaus, Daniela Fischer, and Andrea Sanchini for their expertise and lab assistance. Further, we acknowledge Klaus A. Jarosch for the valuable suggestions about phosphorus data. The thoughtful comments and suggestions by the two anonymous reviewers greatly improved this paper.

Financial support. The project was funded by the Swiss National Science Foundation (grant no. 200021-172586), a Fellowship Grant from the Chinese Scholarship Counsel, and the International PhD Fellowship from the University of Bern.

Review statement. This paper was edited by Helge Niemann and reviewed by two anonymous referees.

\section{References}

Anthony, R. S.: Iron-rich rhythmically laminated sediments in Lake of the Clouds, northeastern Minnesota, Limnol. Oceanogr., 22, 45-54, https://doi.org/10.4319/lo.1977.22.1.0045, 1977.

Appleby, P. G.: Chronostratigraphic techniques in recent sediments, in: Tracking Environmental Change Using Lake Sediments. Basin Analysis, Coring, and Chronological Techniques, edited by: Last, W. M. and Smol, J. P., Springer, Dordrecht, the Netherlands, 171-203, https://doi.org/10.1007/0-306-47669X_9, 2002.

Bennett, K. D.: Determination of the number of zones in a biostratigraphical sequence, New Phytol., 132, 155-170, https://doi.org/10.1111/j.1469-8137.1996.tb04521.x, 1996.

Binderheim-Bankay, E. A.: Sanierungsziel für natürlich eutrophe Kleinseen des Schweizer Mittellandes, PhD thesis, ETH Zurich, Switzerland, 149 pp., 1998.

Bonk, A., Kinder, M., Enters, D., Grosjean, M., Meyer-Jacob, C., and Tylmann, W.: Sedimentological and geochemical responses of Lake Żabińskie (north-eastern Poland) to erosion changes during the last millennium, J. Paleolimnol., 56, 239252, https://doi.org/10.1007/s10933-016-9910-6, 2016.

Boyle, J. F.: Inorganic Geochemical Methods in Palaeolimnology, in: Tracking Environmental Change Using Lake Sediments.
Basin Analysis, Coring, and Chronological Techniques, edited by: Last, W. M. and Smol, J. P., Springer, Dordrecht, the Netherlands, 83-141, https://doi.org/10.1007/0-306-47670-3_5, 2002.

Burley, K. L., Prepas, E. E., and Chambers, P. A.: Phosphorus release from sediments in hardwater eutrophic lakes: the effects of redox-sensitive and-insensitive chemical treatments, Freshwater Biol., 46, 1061-1074, https://doi.org/10.1046/j.13652427.2001.00789.x, 2001.

Butz, C., Grosjean, M., Fischer, D., Wunderle, S., Tylmann, W., and Rein, B.: Hyperspectral imaging spectroscopy: a promising method for the biogeochemical analysis of lake sediments, J. Appl. Remote Sens., 9, 1-20, https://doi.org/10.1117/1.JRS.9.096031, 2015.

Butz, C., Grosjean, M., Goslar, T., and Tylmann, W.: Hyperspectral imaging of sedimentary bacterial pigments: a 1700-year history of meromixis from varved Lake Jaczno, northeast Poland, J. Paleolimnol., 58, 57-72, https://doi.org/10.1007/s10933-017-9955$1,2017$.

Cavalcante, H., Araujo, F. Noyma, N. P., and Becker, V.: Phosphorus fractionation in sediments of tropical semiarid reservoirs, Sci. Total Environ., 619-620, 1022-1029, https://doi.org/10.1016/j.scitotenv.2017.11.204, 2018.

Chen, M., Ding, S., Chen, X., Sun, Q., Fan, X., Lin, J., Ren, M., Yang, L., and Zhang, C.: Mechanisms driving phosphorus release during algal blooms based on hourly changes in iron and phosphorus concentrations in sediments, Water res., 133, 153-164, https://doi.org/10.1016/j.watres.2018.01.040, 2018.

Dittrich, M. and Koschel, R.: Interactions between calcite precipitation (natural and artificial) and phosphorus cycle in the hardwater lake, Hydrobiologia, 469, 49-57, https://doi.org/10.1023/A:1015571410442, 2002.

Dunalska, J. A., Wiśniewski, G., and Mientki, C.: Assessment of multi-year (1956-2003) hypolimnetic withdrawal from Lake Kortowskie, Poland, Lake Reserv. Manage., 23, 377-387, https://doi.org/10.1080/07438140709354025, 2007.

Einsele, W.: Über die Beziehungen des Eisenkreislaufs zum Phosphatkreislauf im eutrophen See, Arch. Hydrobiol., 29, 664-686, 1936.

Einsele, W.: Über chemische und kolloidchemische Vorgänge in Eisen-Phosphat- Systemen unter limnischen and limnogeologischen Gesichtpunkten, Arch. Hydrobiol., 33, 361-387, 1938.

Enters, D., Lücke, A., and Zolitschka, B.: Effects of land-use change on deposition and composition of organic matter in Frickenhauser See, northern Bavaria, Germany, Sci. Total Environ., 369 , 178-187, https://doi.org/10.1016/j.scitotenv.2006.05.020, 2006.

Fastner, J., Abella, S., Litt, A., Morabito, G., Vörös, L., Pálffy, K., Straile, D., Kümmerlin, R., Matthews, D., Phillips, M. G., and Chorus, I.: Combating cyanobacterial proliferation by avoiding or treating inflows with high $\mathrm{P}$ load - experiences from eight case studies, Aquat. Ecol., 50, 367-383, https://doi.org/10.1007/s10452-015-9558-8, 2016.

Frugone-Álvarez, M., Latorre, C., Giralt, S., Polanco-Martínez, J., Bernárdez, P., Oliva-Urcia, B., Maldonado, A., Carrevedo, M.L., Moreno, A., Delgado Huertas, A., and Prego, R.: A 7000year high-resolution lake sediment record from coastal central Chile (Lago Vichuquén, $34^{\circ} \mathrm{S}$ ): implications for past sea level and environmental variability, J. Quaternary Sci., 32, 830-844, https://doi.org/10.1002/jqs.2936, 2017. 
Gächter, R.: Die Tiefenwasserableitung, ein Weg zur Sanierung von Seen, Schweiz. Z. Hydrol., 38, 1-28, 1976.

Gächter, R.: Lake restoration. Why oxygenation and artificial mixing cannot substitute for a decrease in the external phosphorus loading, Aquat. Sci., 49, 176-185, https://doi.org/10.1007/BF02538501, 1987.

Gächter, R. and Müller, B.: Why the phosphorus retention of lakes does not necessarily depend on the oxygen supply to their sediment surface, Limnol. Oceanogr., 48, 929-933, https://doi.org/10.4319/lo.2003.48.2.0929, 2003.

Gächter, R. and Wehrli, B.: Ten years of artificial mixing and oxygenation: no effect on the internal phosphorus loading of two eutrophic lakes, Environ. Sci. Technol., 32, 3659-3665, https://doi.org/10.1021/es9804181, 1998.

GBL: Burgäschisee. Resultate der Wasser- und Planktonuntersuchungen 1977-1995, Office for Water Protection and Waste Management of the Canton of Bern, Bern, 1995.

Giguet-Covex, C., Arnaud, F., Poulenard, J., Enters, D., Reyss, J. L., Millet, L., Lazzaroto, J., and Vidal, O.: Sedimentological and geochemical records of past trophic state and hypolimnetic anoxia in large, hard-water Lake Bourget, French Alps, J. Paleolimnol., 43, 171-190, https://doi.org/10.1007/s10933-0099324-9, 2010.

Gonsiorczyk, T., Casper, P., and Koschel, R.: Phosphorus-binding forms in the sediment of an oligotrophic and an eutrophic hardwater lake of the Baltic Lake District (Germany), Water Sci. Technol., 37, 51-58, https://doi.org/10.1016/S02731223(98)00055-9, 1998.

Grimm, E. C.: CONISS: a FORTRAN 77 program for stratigraphically constrained cluster analysis by the method of incremental sum of squares, Comput. Geosci., 13, 13-35, https://doi.org/10.1016/0098-3004(87)90022-7, 1987.

GSA: 30 Jahre Tiefenwasser-Ableitung. Wie geht es dem Burgäschisee heute?, Office for Water Protection and Waste Management of the Canton of Bern, Bern, 2007.

Guthruf, J., Zeh, M., and Guthruf-Seiler, K.: Kleinseen im Kanton Bern, Water Protection and Waste Management Office of the Canton of Bern, Bern, 1999.

Guthruf, K., Maurer, V., Ryser, R., Zeh, M., and Zweifel, N.: Zustand der Kleinseen, Construction, Transport and Energy Directorate of the Canton of Bern Office for Water and Waste Water and soil protection laboratory, Bern, 2013.

Håkanson, L. and Jansson, M. (Eds.): Principles of Lake Sedimentology, The Blackburn Press, New Jersey, USA, 2002.

Hamilton, S. K., Bruesewitz, D. A., Horst, G. P., Weed, D. B., and Sarnelle, O.: Biogenic calcite-phosphorus precipitation as a negative feedback to lake eutrophication, Can. J. Fish. Aquat. Sci., 66, 343-350, https://doi.org/10.1139/F09-003, 2009.

Heiri, O., Lotter, A. F., and Lemcke, G.: Loss on ignition as a method for estimating organic and carbonate content in sediments: reproducibility and comparability of results, J. Paleolimnol., 25, 101-110, https://doi.org/10.1023/A:1008119611481, 2001.

Holmer, M. and Storkholm, P.: Sulphate reduction and sulphur cycling in lake sediments: a review, Freshwater Biol., 46, 431-451, https://doi.org/10.1046/j.1365-2427.2001.00687.x, 2001.

Hupfer, M. and Lewandowski, J.: Oxygen controls the phosphorus release from lake sediments - a long-lasting paradigm in limnology, Int. Rev. Hydrobiol., 93, 415-432, https://doi.org/10.1002/iroh.200711054, 2008.

Juggins, S.: rioja: analysis of quaternary science data, available at: https://cran.r-project.org/web/packages/rioja/index.html, 2017.

Kaiserli, A., Voutsa, D., and Samara, C.: Phosphorus fractionation in lake sediments-lakes Volvi and Koronia, N. Greece, Chemosphere, 46, 1147-1155, https://doi.org/10.1016/S00456535(01)00242-9, 2002.

Kolzau, S., Wiedner, C., Rücker, J., Köhler, J., Köhler, A., and Dolman, A. M.: Seasonal patterns of nitrogen and phosphorus limitation in four German lakes and the predictability of limitation status from ambient nutrient concentrations, Plos One, 9, e96065, https://doi.org/10.1371/journal.pone.0096065, 2014.

Kosten, S., Huszar, V. L., Bécares, E., Costa, L. S., van Donk, E., Hansson, L. A., Jeppesen, E., Kruk, C., Lacerot, G., Mazzeo, N., and De Meester, L.: Warmer climates boost cyanobacterial dominance in shallow lakes, Glob. Change Biol., 18, 118-126, https://doi.org/10.1111/j.1365-2486.2011.02488.x, 2012.

Kucklentz, V. and Hamm, A. (Eds.): Möglichkeiten und Erfolgsaussichten der Seenrestaurierung, Bayrische Landesanstalt für Wasserforschung, München, Germany, 212 pp., 1988.

LAWA (Länderarbeitsgemeinschaft Wasser): Gewässerbewertung stehende Gewässer: Richtlinie für die Bewertung nach trophischen Kriterien, Germany, 1998.

Lukkari, K., Hartikainen, H., and Leivuori, M.: Fractionation of sediment phosphorus revisited. I: Fractionation steps and their biogeochemical basis, Limnol. Oceanogr.-Meth., 5, 433-444, https://doi.org/10.4319/lom.2007.5.433, 2007.

Mackereth, F. J. H.: Some chemical observations on postglacial lake sediments, Philos. T. R. Soc. B., 250, 165-213, https://doi.org/10.1098/rstb.1966.0001, 1966.

Meyers, P. A. and Ishiwatari, R.: Lacustrine organic geochemistry - an overview of indicators of organic matter sources and diagenesis in lake sediments, Org. Geochem., 20, 867-900, https://doi.org/10.1016/0146-6380(93)90100-P, 1993,

Michel, H., Barci-Funel, G., Dalmasso, J., Ardisson, G., Appleby, P., Haworth, E., and El-Daoushy, F.: Plutonium, americium and cesium records in sediment cores from Blelham Tarn, Cumbria (UK), J. Radioanal. Nucl. Ch., 247, 107-110, https://doi.org/10.1023/A:1006719215833, 2001.

Moosmann, L., Gächter, R. Müller, B., and Wüest, A.: Is phosphorus retention in autochthonous lake sediments controlled by oxygen or phosphorus?, Limnol. Oceanogr., 51, 763-771, https://doi.org/10.4319/lo.2006.51.1_part_2.0763, 2006.

Mikomägi, A., Koff, T., Martma, T., and Marzecová, A.: Biological and geochemical records of human-induced eutrophication in a small hard-water lake, Boreal Environ. Res., 21, 513-527, 2016.

Naeher, S., Gilli, A., North, R. P., Hamann, Y., and Schubert, C. J.: Tracing bottom water oxygenation with sedimentary $\mathrm{Mn} / \mathrm{Fe}$ ratios in Lake Zurich, Switzerland, Chem. Geol., 352, 125-133, https://doi.org/10.1016/j.chemgeo.2013.06.006, 2013.

Nürnberg, G. K.: Lake responses to long-term hypolimnetic withdrawal treatments, Lake Reserv. Manage., 23, 388-409, https://doi.org/10.1080/07438140709354026, 2007.

Oksanen, J., Blanchet, F. G., Kindt, R., Legendre, P., Minchin, P. R., O’hara, R., Simpson, G. L., Solymos, P., Stevens, M. H. H., and Wagner, H.: Package "vegan", Community ecology package, version 2, available at: http://cran.r-project.org/web/packages/ vegan/index.html (last access: 10 September 2019), 2013. 
Pennington, W., Tutin, T. G., Cambray, R. S., and Fisher, E. M.: Observations on lake sediments using fallout ${ }^{137} \mathrm{Cs}$ as a tracer, Nature, 242, 324-326, https://doi.org/10.1038/242324a0, 1973.

R Development Core Team: R: A Language and Environment for Statistical Computing, R Foundation for Statistical Computing, Vienna, Austria, 2017

Reuss, N., Conley, D. J., and Bianchi, T. S.: Preservation conditions and the use of sediment pigments as a tool for recent ecological reconstruction in four Northern European estuaries, Mar. Chem., 95, 283-302, https://doi.org/10.1016/j.marchem.2004.10.002, 2005.

Rey, F., Gobet, E., van Leeuwen, J. F. N., Gilli, A., van Raden, U. J., Hafner, A., Wey, O., Rhiner, J., Schmocker, D., Zünd, J., and Tinner, W.: Vegetational and agricultural dynamics at Burgäschisee (Swiss Plateau) recorded for 18,700 years by multi-proxy evidence from partly varved sediments, Veg. Hist. Archaeobot., 26, 571-586, https://doi.org/10.1007/s00334-017-0635-x, 2017.

Ribeiro, D., Martins, G., Nogueira, R., Cruz, J. V., and Brito, A.: Phosphorus fractionation in volcanic lake sediments (Azores-Portugal), Chemosphere, 70, 1256-1263, https://doi.org/10.1016/j.chemosphere.2007.07.064, 2008.

Richter, T. O., Van der Gaast, S., Koster, B., Vaars, A., Gieles, R., de Stigter, H. C., De Haas, H., and van Weering, T. C.: The Avaatech XRF Core Scanner: technical description and applications to NE Atlantic sediments, Geol. Soc. Lond. Spec. Publ., 267, 39-50, https://doi.org/10.1144/GSL.SP.2006.267.01.03, 2006.

Rydin, E.: Potentially mobile phosphorus in Lake Erken sediment, Water Res., 34, 2037-2042, https://doi.org/10.1016/S00431354(99)00375-9, 2000.

Schmid, S. M., Fügenschuh, B., Kissling, E., and Schuster, R.: Tectonic map and overall architecture of the Alpine orogen, Eclogae Geol. Helv., 97, 93-117, https://doi.org/10.1007/s00015004-1113-x, 2004.

Schneider, T., Rimer, D., Butz, C., and Grosjean, M.: A highresolution pigment and productivity record from the varved Ponte Tresa basin (Lake Lugano, Switzerland) since 1919: insight from an approach that combines hyperspectral imaging and highperformance liquid chromatography, J. Paleolimnol., 60, 381-398, https://doi.org/10.1007/s10933-018-0028-x, 2018.

Schnurrenberger, D., Russell, J., and Kelts, K.: Classification of lacustrine sediments based on sedimentary components, J. Paleolimnol., 29, 141-154, https://doi.org/10.1023/A:1023270324800, 2003.

Smith, L., Watzin, M. C., and Druschel, G.: Relating sediment phosphorus mobility to seasonal and diel redox fluctuations at the sediment-water interface in a eutrophic freshwater lake, Limnol. Oceanogr., 56, 2251-2264, https://doi.org/10.4319/lo.2011.56.6.2251, 2011.

Søndergaard, M., Jensen, P. J., and Jeppesen, E.: Retention and internal loading of phosphorus in shallow, eutrophic lakes, Sci. World J., 1, 427-442, https://doi.org/10.1100/tsw.2001.72, 2001.
Stevens, L., Ito, E., and Olson, D.: Relationship of Mncarbonates in varved lake-sediments to catchment vegetation in Big Watab Lake, MN, USA, J. Paleolimnol., 24, 199-211, https://doi.org/10.1023/A:1008169526577, 2000.

Trolle, D., Hamilton, D. P., and Pilditch, C. A.: Evaluating the influence of lakemorphology, trophic status and diagenesis on geochemical profiles in lake sediments, Appl. Geochem., 25, 621632, https://doi.org/10.1016/j.apgeochem.2010.01.003, 2010.

Tu, L., Jarosch, K. A., Schneider, T., and Grosjean, M.: Phosphorus fractions in sediments and their relevance for historical lake eutrophication in the Ponte Tresa basin (Lake Lugano, Switzerland) since 1959, Sci. Total Environ., 685, 806-817, https://doi.org/10.1016/j.scitotenv.2019.06.243, 2019a.

Tu, L., Zander, P., Szidat, S., Lloren, R., and Grosjean, M.: Geochemical parameters determined in sediment cores from Lake Burgäschi, Switzerland, PANGAEA, https://doi.org/10.1594/PANGAEA.908896, 2019b.

Tylmann, W., Bonk, A., Goslar, T., Wulf, S., and Grosjean, M.: Calibrating ${ }^{210} \mathrm{~Pb}$ dating results with varve chronology and independent chronostratigraphic markers: Problems and implications, Quat. Geochronol., 32, 1-10, https://doi.org/10.1016/j.quageo.2015.11.004, 2016.

van Raden, U. J.: High-resolution Swiss lake records of climate change, $\mathrm{PhD}$ thesis, ETH Zurich, Switzerland, https://doi.org/10.3929/ethz-a-009783578, 2012.

von Büren, G.: Der Burgäschisee, Mitteilungen der Naturforschenden Gesellschaft, Bern, 83 pp., 1949.

Whitehouse, R. D.: Phosphorus scavenging through calcite coprecipitation: bringing clarity to Clear Lake, BSc thesis, University of British Columbia, Canada, 2010.

Wirth, S. B., Gilli, A., Niemann, H., Dahl, T. W., Ravasi, D., Sax, N., Hamann, Y., Peduzzi, R., Peduzzi, S., Tonolla, M., and Lehmann, M. F.: Combining sedimentological, trace metal (Mn, Mo) and molecular evidence for reconstructing past watercolumn redox conditions: The example of meromictic Lake Cadagno (Swiss Alps), Geochim. Cosmochim. Ac., 120, 220 238, https://doi.org/10.1016/j.gca.2013.06.017, 2013.

Żarczyński, M., Tylmann, W., and Goslar, T.: Multiple varve chronologies for the last 2000 years from the sediments of Lake Żabińskie (northeastern Poland)-Comparison of strategies for varve counting and uncertainty estimations, Quat. Geochronol., 47, 107-119, https://doi.org/10.1016/j.quageo.2018.06.001, 2018.

Żarczyński, M., Wacnik, A., and Tylmann, W.: Tracing lake mixing and oxygenation regime using the $\mathrm{Fe} / \mathrm{Mn}$ ratio in varved sediments: 2000 year-long record of human-induced changes from Lake Zabinskie (NE Poland), Sci. Total Environ., 657, 585-596, https://doi.org/10.1016/j.scitotenv.2018.12.078, 2019. 